\title{
An Evaluation of Climate Mitigation Adoption Technologies in Improving Rural Households' Livelihood Outcomes: The Case of Eastern Oromia, Ethiopia
}

\author{
Beyan Ahmed Yuya ${ }^{1^{*}}$, Nano Alemu Daba ${ }^{2}$ \\ ${ }^{1}$ School of Agricultural Economics and Agribusiness, Haramaya University. P.O.box 95 Dire Dawa, Ethiopia \\ ${ }^{2}$ School of Plant Sciences, Haramaya University. P.O.box 95 Dire Dawa, Ethiopia
}

\begin{tabular}{l}
\hline A R T I C L E I N F O \\
Research Article \\
Received 26 December 2017 \\
Accepted 27 March 2018 \\
\hline
\end{tabular}

Keywords: Adoption technologies

Livelihood outcomes

Multivariate probit

Propensity score matching.

*Corresponding Author:

E-mail: beyanhmd@gmail.com
Climate mitigation \begin{abstract}
A B S T R A C T
Agricultural technologies are seen as an important route out of poverty in most of the developing countries. However, the rates of adoption of these technologies have remained low in most of these countries. This study aim at shedding some light on an evaluation of climate mitigation agricultural adoption technologies, and its contribution to rural livelihood outcomes in Gurawa district using cross sectional data collected from randomly selected 180 sample households during the 2016 crop production season. Multivariate probit and Propensity score matching was used to identify impacts of adoption technologies, and to identify factors affecting smallholder farmers' multiple technology adoption decisions. The results showed that the probability of adoption of agricultural technologies are influenced by several factors: family size, economical active members, education level, age of the household head, social status, soil fertility status, distance from extension office, land holding, distance to markets and distance to weather road. The impact evaluation results indicated that on average, the participation household in soil conservation has increased food security status and asset accumulation nearly by $38 \%$ and $15 \%$, respectively, however it decreases the rate of poverty nearly by 51 percent. Use of improved seeds increased food security status and decreased poverty rate nearly by $38 \%$ and $44 \%$, respectively. On the other hand, use of irrigation technology increased food security status and asset accumulation nearly by $23 \%$ and $31.8 \%$, respectively, whereas it decreases the rate of poverty nearly by 29 percent. Similarly, adoption of row planting methods increased food security status and asset accumulation nearly by $28.7 \%$ and $15.5 \%$, respectively, whereas it decreases the rate of poverty nearly by 51.5 percent. Therefore, policy makers should give due emphasis to the aforementioned variables to increase adoption technologies and improve the livelihood of the rural households.
\end{abstract}

DOI: https://doi.org/10.24925/turjaf.v6i6.710-718.1771

\section{Introduction}

Agriculture is the most important sector in the Ethiopian economy sharing $38.5 \%$ of the national GDP, and crop accounted for $27.4 \%$ (NPC, 2016), and it also provides employment for $72.7 \%$ of the total population (UNDP, 2015). Moreover, Ethiopian agriculture is dominated by smallholder farming which accounts for $85 \%$ of households farming less than two hectors and $40 \%$ less than 0.5 ha (FAO, 2014). Ethiopia has a population of about 96.6 million, more than four out of every five live in rural areas and are small-holder rain-fed agricultural production (World Bank, 2014). According to World Bank data, in 2010, food aid was equivalent to 13 percent of its national output and in 2014 nearly 30 percent of households in the country were in extreme poverty. The country receives more food aid than any other country in the world (Kirwan and Margaret, 2007), and the depth and intensity of food insecurity are high (Bogale and Shimelis, 2009; Zegeye and Hussien, 2011).

The main challenge for agriculture in the twenty-first century is the need to nourish increasing numbers of people while conserving the ongoing soil degradation and water depletion in the face of limited resources and growing pressures associated with an increasing global population and changing diets (Tubiello, 2012). Climate change is already putting extra pressure on agriculture and its effects are expected to become more vital in the future (Apata et al., 2009; Lobell et al., 2011b; Rosenzweig et al., 2014). Despite technological advancement, the agricultural system is still highly dependent on the climatic condition in many areas of the world (Müller et al., 2011). 
Climate change affects agriculture directly and indirectly. Directly, it affects by influencing the weather variables such as rainfall, temperature, solar radiation, wind speed and humidity (Sowunmi, 2010; Pryor et al., 2014; Arimi, 2014). Indirectly, it affects through disease and pest outbreak as well as favoring the development of climate related diseases like malaria that affect the workforce (Newton et al., 2011). Climate change studies indicated that developing nations are expected to withstand the worst of the associated damages (Ericksen et al., 2011; Skoufias et al., 2011). Sub-Saharan Africa (SSA) is arguably the most vulnerable region to many unpleasant effects of climate change due to a very high dependence on rain-fed agriculture (Cooper et al., 2008). Thus, the impacts of climate change are likely to fall unreasonably on poorer nations and on poorer households. Ethiopia is among the most vulnerable countries in SSA due to its great reliance on climate vulnerable economy (Conway and Schipper, 2011).

Increasing agricultural productivity is critical to meet expected rising demand and, as such, it is instructive to examine recent performance in cases of modern agricultural technologies (Challa, 2013). Agricultural technologies include all kinds of improved techniques and practices which affect the growth of agricultural output (Jain et al., 2009). According to Loevinsohn et al. (2013) the most common areas of technology development and promotion for crops include new varieties and management regimes; soil as well as soil fertility management; weed and pest management; irrigation and water management.

Low external input strategies involve different agronomic practices, such as soil and water management practices and use of organic manure (Priscilla et al., 2014). Teklewold et al. (2013) indicated that the adoption of cropping system diversification, conservation tillage and modern varieties increases income from maize production. Kassie et al. (2015) also indicated that combining conservation agriculture with certified seeds and other external inputs could lead to positive effects. There is no single approach that will work in every situation and the suitability of these technologies varies under different conditions (Priscilla et al., 2014). Therefore, more research is required to show comparative evidence of what really works under which conditions.

Adoption of improved agricultural technologies has been associated with: higher earnings and lower poverty; improved nutritional status; lower staple food prices; increased employment opportunities as well as earnings for landless laborers (Kasirye, 2010). This has made the dynamics of technical change in agriculture to be an area of intense research since the early part of twentieth century (Loevinsohn et al., 2013). These technologies are particularly relevant to smallholder farmers in developing countries because they are constrained in many ways, which makes them a priority for development efforts.

Over the years many studies have been conducted on innovation and uptake of new technologies in developing countries. In addition the process of adoption and the impact of adopting new technology on smallholder farmers have been studied. However new agricultural technologies are often adopted slowly and several aspects of adoption remain poorly understood despite being seen as an important route out of poverty in most of the developing countries (Bandiera and Rasul, 2010; Simtowe, 2011).

The rural household livelihood outcomes included the following indicators: improved food security, increased income, health, education, housing and household facilities/assets owned by the household members. Dairy farming, crop production and non- farm activities are livelihood strategies which significantly determine the household livelihood outcomes. These outcomes include improved food security, increased household income, access to health and education, improved housing and household facilities or assets owned (Kenneth Muganyizi, 2011).

Generally; Livelihood outcomes includes: more income, increased welfare, which includes non-material goods, like self-esteem, health status, access to services, sense of inclusion, reduced vulnerability such as better resilience through an increase in asset status, improved food security which might be due to increase in financial capital in order to buy food and more sustainable use of natural resources, like appropriate property rights are the final achievements reached from the livelihood strategies implemented by the household (Ahmad and Sultana, 2014). In this study household level poverty, food security status and asset accumulation were used as livelihood outcomes.

Therefore, adaptation strategies that minimize the negative outcomes associated with changing climate are urgently needed. Since a society with high adaptive capacity will be less susceptible in the future than other communities to the potentially detrimental and often unpredictable effects of climate change (Petheram et al., 2010). However, most of the farmers in the country have low access to education, information, technology, and basic social and support services, and, as a result, have low adaptive capacity to deal with the consequences of climate variability and change (WB, 2010). Focusing on single technologies, such studies ignore the possibility that the choice of climate mitigation technologies to be adopted may be partly dependent on earlier technology choices (Teklewold et al., 2013).

The objective of this study was therefore to identify the nature of the relationship that exists between agricultural technologies and its contribution in improving rural livelihood outcomes in eastern Oromia, Ethiopia.

\section{Materials and Methods}

\section{Description of the Study Area}

The study was conducted in East Hararghe zone of Oromia reginal state of Ethiopia. The zone is geographically located between $7^{\circ} 32^{\prime}$ - $9^{\circ} 44^{\prime}$ North latitude and $41^{\circ} 10^{\prime}-43^{\circ} 16^{\prime}$ East longitudes with altitude ranging from 500 to 3405 meters above sea level. The Zone has a total population of 2,723,850 of whom 50.8 percent are men and 49.2 percent are women with population density of 151.87 persons per $\mathrm{km} 2$ and unevenly distributed (CSA, 2016). Of the total population of the zone 87.4 percent, 12.6 percent, and 1.11 percent are residents of rural, urban and pastoralists, respectively. This study was focus on adoption of cropping technologies (improved seeds, line planting, use of 
irrigation and soil conservation) at the farm household level in Gurawa districts of East hararghe zone particularly.

\section{Sources of Data and Methods of Data Collection}

As sources of information both primary and secondary data sources were used. The primary data were collected by the trained enumerators. In addition to primary data, secondary data was also collected from relevant sources such as published and unpublished documents from the relevant institutions for general description and to augment primary data.

\section{Sample Size and Sampling Technique}

Gurawa districts was selected purposively due there potential area for cereal crops and problems of rural households livelihoods. From this district two peasant associations were selected purposively because of their accessibility. Then the sample from each peasant association selected randomly based on probability proportion to size. Finally, a total of 180 sample respondents were interviewed.

\section{Methods of Data Analysis}

To address the objective of the study, both preliminary statistics and econometric methods were employed. In order to achieve the objective, the study was employed Multivariate Probit and propensity score matching econometric models.

\section{Food Security Measure}

Food security pillars - access, availability, utilization and stability - are frequently cited in the literature as organizing principles for food security measurement (Jones et al., 2011; Carletto et al., 2012; Coates, 2013). However, many authors note that the "pillars" analogy can hamstring improved food security measurement efforts because each one has not been well-defined (Berry, 2015; Coates, 2013; Moltedo et al., 2014). Household surveys yield information about household expenditure decisions and take the actual demographic structure of the household into account (de Haen, 2011). They are also costly to implement and tend to be infrequently administered (Jones et al., 2013; de Haen, 2011). Perhaps recent research suggests household food consumption expenditure results can vary significantly based on survey design, with some authors arguing this should be only be used with great caution until more consistent and comparable survey data collection can be completed (de Weerdt et al., 2015; Carletto et al., 2012). Therefore, in this study household food expenditure was used. In this measure the frequency of dietary food consumption of different food groups consumed by a household during the last 7 days before the survey was calculated and consumption score is then calculated using weights assigned to each food group using the cut-off point of 2200 kilocalories as the minimum caloric requirement, used by official reports in Ethiopia (MOFED, 2013).

\section{Construction of Poverty Indexes}

Based on poverty line, three poverty measures that were identified by Foster et al. (1984) were employed.
The headcount index indicates the proportion of population regarded as poor. If population size is $n$ and $P$ is the number of poor people then the headcount index is represented as;

$$
\text { Headcount Index }(\mathrm{HC})=\frac{\mathrm{P}}{\mathrm{n}}
$$

On the other hand, poverty gap index highlights how much are the poor below the poverty line on average. If $\mathrm{Z}$ is poverty line, $Y_{i}$ is the per capita income of $i$, then the poverty gap is;

$$
\text { Poverty Gap }(\mathrm{PG})=1 / \mathrm{n} \sum_{\mathrm{i}=1}^{\mathrm{n}}\left[\frac{\mathrm{Z}-\mathrm{Y}_{\mathrm{i}}}{\mathrm{z}}\right]
$$

In the equation, $\mathrm{z}-\mathrm{y}_{\mathrm{i}}=0$ if $\mathrm{y}_{\mathrm{i}}>\mathrm{z}$.

Squared poverty gap measures the severity of poverty giving more weight to the poor and is depicted as follows:

$$
\text { Squared poverty gap }(\mathrm{GP})^{2}=1 / \mathrm{n} \sum_{\mathrm{i}=1}^{\mathrm{n}}\left(\frac{\mathrm{Z}-\mathrm{Y}_{\mathrm{i}}}{\mathrm{Z}}\right)^{2} \text { (3) }
$$

The general formula for all these three measures, which depend on parameter, $\alpha$ is given below;

$$
\mathrm{p}_{(\alpha)}=1 / \mathrm{n} \sum_{\mathrm{i}=1}^{\mathrm{q}}\left(\frac{-\mathrm{Y}_{\mathrm{i}}}{\mathrm{Z}}\right)
$$

Where $\alpha$ takes a value of zero for the headcount index, one for the poverty gap index and two for the squared poverty gap index.

\section{Technology Adoption Determinants}

The study was adopt multivariate probit (MVP) econometric technique to simultaneously model the influence of the set of explanatory variables on each of the different climate mitigation strategies, while allowing the unobserved and/or unmeasured factors (error terms) to be freely correlated (Lin et al., 2005). The dependent variable in this study is the choice of an adaptation option(s) from the set of farm level adaptation measures (improved crop varieties, row planting, use of compost, use of irrigation and soil conservation practices). Following Lin et al. (2005), the multivariate probit econometric approach for this study is characterized by a set of $\mathrm{m}$ binary dependent variables $Y_{h p j}$ such that:

$$
\begin{aligned}
& Y_{h p j}^{*}=X_{h p j}^{\prime} \beta_{j}+U_{h p j} \quad j=1,2, \ldots m \text { and } \\
& Y_{h p j}=\left\{\begin{array}{l}
1 \text { if } Y_{h p j}^{*}>0 \\
0 \text { otherwise }
\end{array}\right.
\end{aligned}
$$

Where $j=1,2 \ldots$ m denotes the adaptation technologies available; $X_{h p j}^{\prime}$ is a vector of explanatory variables, $\beta_{j}$ denotes the vector of parameter to be estimated, and $U_{h p j}$ are random error terms distributed as multivariate normal distribution with zero mean and unitary variance. It is assumed that a rational $h^{\text {th }}$ farmer has a latent variable, $Y_{h p j}^{*}$ which captures the unobserved preferences or demand associated with the $j^{\text {th }}$ choice of adaptation strategy. This latent variable is assumed to be a linear combination of observed household and other characteristics that affect the adoption of adaptation strategy, as well as unobserved characteristics captured by stochastic error term. 


\section{Propensity Score Matching (PSM) Method}

In addition to mean comparison, the study used PSM to estimate the individual impact of climate mitigation agricultural adoption technologies on rural households' livelihood outcomes. In the case of a binary treatment the treatment indicator $D_{i}$ equals one if individual i receives treatment and zero otherwise. The impact of a treatment for an individual $i$, noted $T i$, is defined as the difference between potential outcome in case of treatment and potential outcome in absence of treatment:

$$
\mathrm{T}_{\mathrm{i}}=\mathrm{Y}_{\mathrm{i}}(1)-\mathrm{Y}_{\mathrm{i}}(0)
$$

The fundamental evaluation problem arises because only one of the potential outcomes is observed for each individual $i$. The unobserved outcome is called counterfactual outcome. Hence, estimating the individual treatment effect $i$ is not possible and one has to concentrate on (population) average treatment effects.

ATT, which measures the impact of the program on those individuals who participated:

$$
\mathrm{T}^{\mathrm{ATT}}=\mathrm{E}[(\mathrm{T}) \mathrm{D}=1]=\mathrm{E}[\mathrm{Y}(1) \mid \mathrm{D}=1]-\mathrm{E}[\mathrm{Y}(0) \mid \mathrm{D}=1]
$$

The second term - $\mathrm{E}[\mathrm{Y}(0) \mid \mathrm{D}=1]$ is not observed, we do observe $\mathrm{E}[\mathrm{Y}(0) \mid \mathrm{D}=0]$ thus:

$$
\begin{aligned}
& \mathrm{E}[\mathrm{Y}(1) \mid \mathrm{D}=1]-\mathrm{E}[\mathrm{Y}(0) \mid \mathrm{D}=0]=\mathrm{T}^{A T T}+\mathrm{E}[\mathrm{Y}(0) \mid \mathrm{D}=1]- \\
& \mathrm{E}[\mathrm{Y}(0) \mid \mathrm{D}=0]
\end{aligned}
$$

The difference between the left hand side and ATT is the so-called 'self-selection bias'. The true parameter $\mathrm{T}^{A T T}$ is only identified, if:

$$
\mathrm{E}[\mathrm{Y}(0) \mid \mathrm{D}=1]-\mathrm{E}[\mathrm{Y}(0) \mid \mathrm{D}=0]=0
$$

For any adopter, there is non-adopter household with closest propensity score as the match. Thus the mean impact of agricultural technology adoption on households' welfare is given by:

$$
\Delta_{\mathrm{i}}=\frac{\sum_{\mathrm{j}=1}^{\mathrm{p}} \mathrm{Y}_{\mathrm{ij} 1}-\sum_{\mathrm{i}=1}^{\mathrm{NP}} \mathrm{Y}_{\mathrm{ij} 0}}{\mathrm{P}}
$$

Where $Y_{j 1}$ is the farm households' food security status, poverty level or asset accumulation of technology adopter household j, $Y_{i j o}$ is the farm households' food security status, poverty level or asset accumulation of the $i^{\text {th }}$ non-adopter household will be matched to the $j^{\text {th }}$ adopter household, $\mathrm{P}$ is the total number of adopters and NP is the total number of non-adopters.

\section{Result and Discussion}

The results of the correlation coefficients of the error terms from the MVP were significant for any pairs of equations $(\mathrm{P}<0.000)$ and they were statistically different from zero in four of the eight cases (Table 1), confirming the appropriateness of the MVP specification. The marginal success probability for each equation (adoption decision) is reported below. The likelihood of adopting row planting practice is relatively low (42\%) as compared to the probability of adopting improved seeds (63\%), soil conservation $(79 \%)$ and irrigation use $(50 \%)$. This is a good evidence to suggest that availability of technical and appropriate support on row planting practice is a challenge.

The joint probabilities of success or failure of adoption of the four agricultural technologies suggest that households are more likely to jointly adopt the four technologies. The likelihood of households to jointly adopt the four technologies is about $6.0 \%$ compared to their failure to jointly adopt them $(1.0 \%)$. The results of correlation coefficients of the error terms indicate that there was positive (complementarities) and negative correlation (substitutability) between different technologies.

The simulated maximum likelihood estimation results indicated that there were positive and significant relationships between household decision to adopt row planting and soil conservation and irrigation use and improved seed. The results also show that there were negative and significant relationships between adoption of improved seed and soil conservation; and adoption of irrigation and soil conservations. Similarly, there were negative and significant relationships between adoption of improved seed and line planting; and adoption of irrigation and row planting. The relationship between improved seeds and irrigation use is plausible because both technologies utilized together and the substitutability of improved seed and row planting are not expected especially in smallholder farms.

The result showed that there was no clear demarcation between technologies and farmers might combine different technologies or they might substitute each other. This might be due to the nature of plurality of the role of extension workers in the country. In Ethiopia, extension workers are the main source of information for smallholder farmers regarding most of farming activities. They advise and consult farmers about the importance of improved seed, irrigation technology, compost, crop rotation, row planting and soil and water conservation simultaneously.

Table 1 Coefficients (R) correlation matrix of the technologies

\begin{tabular}{l|cccc}
\hline \multicolumn{1}{c|}{ Variables } & Soil Conservation & Improved Seeds & Irrigation use & Line planting \\
\hline Improved seeds & -0.204 & & & \\
Irrigation use & -0.032 & $0.48^{* * *}$ & $-0.41 * * *$ & 0.42 \\
Line planting & $0.34 * * *$ & $-0.60 * * *$ & 0.50 & 0.63 \\
Predicted probability & 0.79 & 0.030 .0000
\end{tabular}

Joint probability (success) 0.060 , Joint probability (failure) 0.01 , Likelihood ratio test of Rhoij $=0$ Prob $>\operatorname{chi}^{2}(6)=0.0000$

***, means significant at $1 \%$ probability level 
Table 2 Coefficients of multivariate probit simulation for households' technology adoption decisions.

\begin{tabular}{l|cccc}
\hline \multicolumn{1}{c|}{ Variables } & Soil Conservation & Improved Seeds & Irrigation use & Line planting \\
\hline Sex & -.0797181 & .5923457 & .3657095 & .2565803 \\
Age & -.0017782 & $-.0736396^{*}$ & .0170273 & $.0901934 * *$ \\
Education & $.1076343^{* *}$ & -.0022722 & $.055482 * * *$ & .021373 \\
Family size & .0595098 & -.0191088 & $-.1342744 *$ & -.0096344 \\
Economic active & .0314686 & -.0742776 & $.2267686^{*}$ & .1426732 \\
Cultivated area & .0254502 & .0278704 & -.2852852 & $.2959976^{*}$ \\
Livestock holding & .0404032 & -.0713917 & -.0239731 & .0720536 \\
Mkt distance & .0013719 & -.0150616 & .0310804 & $-.0822588^{* *}$ \\
Farmers training & .3402714 & -.3004716 & .229923 & .0153273 \\
DA office distan & .0013271 & -.0128069 & $-.0348643 * * *$ & $-.0189087 * *$ \\
Credit access & -.2186045 & .2315269 & .2073435 & .3423607 \\
Social status & $.5569018 * *$ & $.5636045 * *$ & $1.083255^{* * *}$ & -.0373011 \\
Soil fertility status & $.6441971 * *$ & -.2923478 & -.0835368 & .2779614 \\
Weather road dist & .0055569 & $-.0228729 * * *$ & -.0003903 & -.0032254 \\
Constant & -1.088002 & -.56068 & $2.112023^{*}$ & $-1.913304 *$ \\
\hline
\end{tabular}

Number of obs $=180$, Wald chi $^{2}(52)=135.90$, Log likelihood $=-374.60988$, Prob $>$ chi $^{2}=0.0000$

$* * *, * *$ and $*$ significant at $1 \%, 5 \%$ and $10 \%$ probability level, respectively

Although farmers adopt a combination of technologies, there are a number of factors that can influence their decision to choose a particular technology. This section has identified the variables which determine the adoption of various technologies using MVP. Fourteen explanatory variables, of which five dummy and nine continuous variables were included in the model. The selection of those explanatory variables for the model was done through literature review.

Education was found to have a positive relationship with adoption of soil conservation; educations of smallholder farmers increase their awareness of adoption technologies and in turn facilitate the rate of new technology adoption. The result of this study also shows that as the participation in social status increases the adoption of soil conservation.

As in the adoption decision, the framers' education had a significant and positive effect on the adoption of row planting practices. As the farmers access to education increases, the probability of adopting row planting practices also increases. This is because farmers' education may provide smallholder farmers awareness on the importance of row planting and the rate of its application to their farm production. Soil fertility status was related to soil conservation positively. The positive relationship might be due to the fact that farmers with high fertile land are more sensitive to land degradation problem and has awareness of benefit of adopting soil conservation practices.

Age has a negative relationship with adoption of improved seed. This is because in the real context, farmers in the study area not sell cereal crops and mostly focus on vegetable and other cash crops for markets. The result also indicated that there is a negative relationship between line planting and market distance indicating as market distance increases it is difficult to supply inputs and improved seeds that might consumed with row planting technology. This is reasonable, because weather road distance contributes to higher transport and transaction costs, so that the use of purchased inputs is less likely in remote areas.
Access to social status was found to have a positive relationship with use of irrigation and adoption of improved seeds. Distance from development agents' office has a negative relationship with irrigation use and row planting practices. Family size and economic active member was found to have negative and positive relationship with adoption of irrigation technology. Age and cultivated area were positively related with adoption of line planting practices, whereas weather road distance was found to have negative relationships with adoption of improved seeds.

\section{Distribution of Estimated Propensity Scores for} Different Adoption Technologies

The common support region is the area which contains the minimum and maximum propensity scores of treatment and control group households, respectively. It requires deleting of all observations whose propensity scores is smaller than the minimum and larger than the maximum of treatment and control, respectively (Caliendo and Kopeinig, 2005). Accordingly, in this study the common support region would lie between 0.1 and 0.89. In other words, households whose estimated propensity score was less than 0.1 and larger than 0.89 were not considered for the matching exercise. As a result of this restriction, 12 households (11 participant and 1 non-participant households) were discarded.

In the case of improved seeds adoption technology, in this study the common support region would lie between 0.1 and 0.88 . In other words, households whose estimated propensity score was less than 0.1 and larger than 0.88 are not considered for the matching exercise. As a result of this restriction, 4 households ( 2 participants and 2 nonparticipant households) were discarded.

For irrigation adoption technology, in the present study the common support region would lie between 0.1 and 0.89. On the other words, households whose estimated propensity score was less than 0.1 and larger than 0.89 were not considered for the matching exercise. As a result of this restriction, 27 households (19 participant and 8 non-participant households) were discarded. 
Table 3 Distribution of estimated propensity score for soil conservation technology

\begin{tabular}{l|ccccc}
\hline \multicolumn{1}{c|}{ Variable } & Obs & Mean & Std. Dev. & Min & Max \\
\hline All households & 180 & 0.5333333 & 0.206436 & 0.1000442 & 0.925607 \\
Adopters & 124 & 0.579241 & 0.18787 & 0.1000442 & 0.925607 \\
Non-adopters & 56 & 0.4316807 & 0.210926 & 0.1020104 & 0.8895481 \\
\hline
\end{tabular}

Table 4 Distribution of estimated propensity score for improved seeds technology

\begin{tabular}{l|ccccc}
\hline \multicolumn{1}{c|}{ Variable } & Obs & Mean & Std. Dev. & Min & Max \\
\hline All households & 180 & 0.5333333 & 0.206436 & 0.1000442 & 0.925607 \\
Adopters & 115 & 0.5449453 & 0.2053339 & 0.1000442 & 0.925607 \\
Non-adopters & 65 & 0.5127892 & 0.2083725 & 0.1431605 & 0.8862918 \\
\hline
\end{tabular}

Table 5 Distribution of estimated propensity score for irrigation technology

\begin{tabular}{l|ccccc}
\hline \multicolumn{1}{c|}{ Variable } & Obs & Mean & Std. Dev. & Min & Max \\
\hline All households & 180 & 0.5333333 & 0.206436 & 0.1000442 & 0.925607 \\
Adopters & 96 & 0.5702905 & 0.1952544 & 0.1400876 & 0.925607 \\
Non-adopters & 84 & 0.4910966 & 0.2118608 & 0.1000442 & 0.8895481 \\
\hline
\end{tabular}

Table 6 Distribution of estimated propensity score for line planting adoption practice

\begin{tabular}{l|ccccc}
\hline \multicolumn{1}{c}{ Variable } & Obs & Mean & Std. Dev. & Min & Max \\
\hline All households & 180 & 0.5333333 & 0.206436 & 0.1000442 & 0.925607 \\
Adopters & 96 & 0.6141519 & 0.1879761 & 0.1000442 & 0.8895481 \\
Non-adopters & 84 & 0.4409693 & 0.1878142 & 0.1020104 & 0.925607 \\
\hline
\end{tabular}

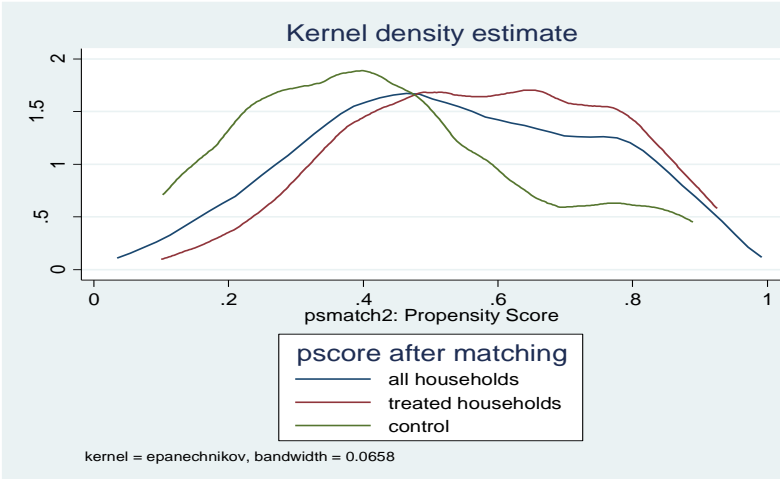

Figure 1 Soil conservation technology kernel density distribution of propensity score

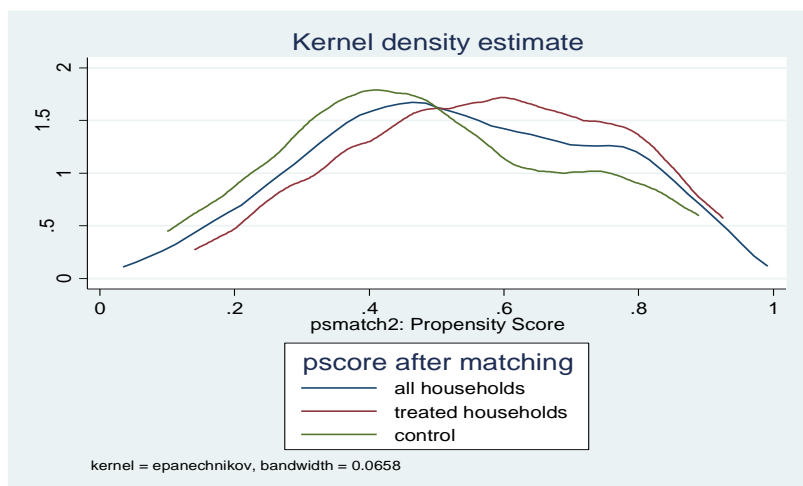

Figure 3 Irrigation technology kernel density distribution of propensity score

In the case of row planting adoption practice, in this study the common support region would lie between 0.1 and 0.89 . In other words, households whose estimated propensity score was less than 0.1 and larger than 0.89 were not considered for the matching exercise. As a result of this restriction, 2 households (1 participant and 1 nonparticipant household) were discarded.

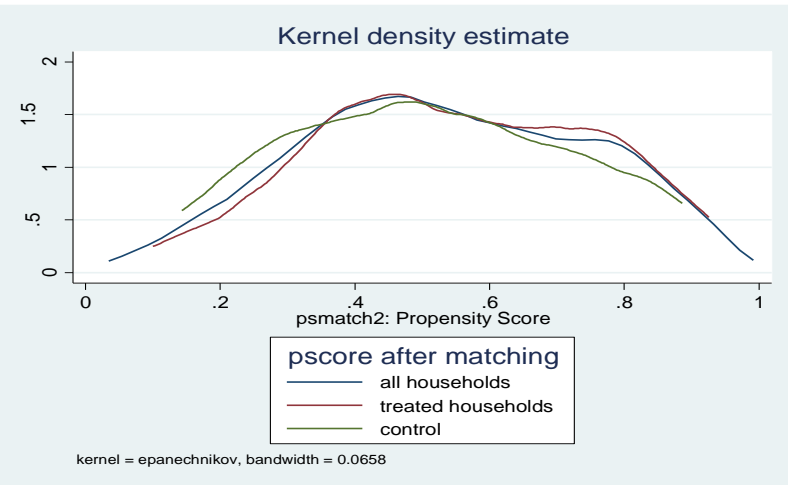

Figure 2 Improved seeds technology kernel density distribution of propensity score

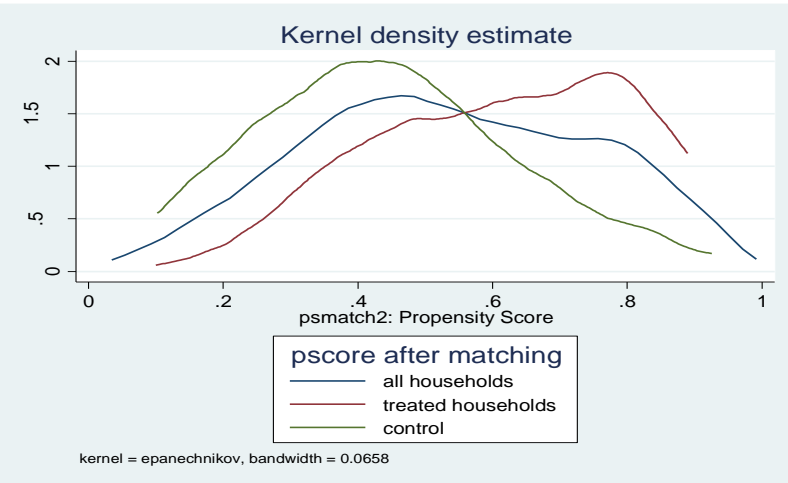

Figure 4 Line planting adoption practice kernel density distribution of propensity score

\section{Results of Impact Evaluations}

Impacts of Soil Conservation on Rural Livelihood Outcomes

This section provides evidence as to whether or not the climate mitigation technologies have brought significant changes on rural livelihood outcomes. The 
estimation result provides a supportive evidence of statistically significant effect of adoption technologies on rural household livelihood outcomes measured by food security status, poverty status and asset accumulation. After controlling for pre-participation differences in demographic, location and asset endowment characteristics of the user and non- user households, it has been found that, on average, the participant household in soil conservation has increased food security status and asset accumulation nearly by $38 \%$ and $15 \%$ respectively. Whereas it decreases the rate of poverty by nearly by 51 percents (Table 7).

Impacts of improved seeds on rural livelihood outcomes

After controlling for pre-participation differences in demographic, location and asset endowment characteristics of the user and non- user households, it has been found that, on average, the participant household in improved seeds has increased food security status nearly by $38 \%$. Whereas as it decreases the rate of poverty nearly by 44 percent (Table 8 ).

Impacts of irrigation use on rural livelihood outcomes

The estimation result provides a supportive evidence of statistically significant effect of adoption technologies on rural household livelihood outcomes measured by food security status, poverty status and asset accumulation. After controlling for pre-participation differences in demographic, location and asset endowment characteristics of the user and non- user households, it has been found that, on average, the participant household in irrigation has increased food security status and asset accumulation nearly by $23 \%$ and $31.8 \%$ respectively. Whereas it decreases the rate of poverty nearly by 29 percents (Table 9).

Impacts of line planting on rural livelihood outcomes

The estimation result provides a supportive evidence of statistically significant effect of adoption technologies on rural household livelihood outcomes measured by food security status, poverty status and asset accumulation. After controlling for pre-participation differences in demographic, location and asset endowment characteristics of the user and non- user households, it has been found that, on average, the participant household in line planting has increased food security status and asset accumulation nearly by $28.7 \%$ and $15.5 \%$ respectively, Whereas it decreases the rates of poverty status nearly by 51.5 percent (Table 10).

Table 7 Impacts of soil conservation on rural livelihoods

\begin{tabular}{l|cccccc}
\hline \multicolumn{1}{c|}{ Variable } & Sample & Treated & Controls & Difference & S.E. & T-stat \\
\hline Food security & ATT & 0.707964602 & 0.428111374 & 0.279853228 & 0.082314201 & $3.40^{* * *}$ \\
Poverty status & ATT & 0.353982301 & 0.741979901 & -0.3879976 & 0.076722604 & $-5.06 * * *$ \\
Asset value & ATT & 82874.0885 & 70166.7671 & 12707.3214 & 4206.66394 & $3.02 * * *$ \\
\hline
\end{tabular}

Sources: own result, 2017. *** means significant at $1 \%$ probability level

Table 8 Impacts of improved seeds on rural livelihood outcomes

\begin{tabular}{l|cccccc}
\hline \multicolumn{1}{c|}{ Variable } & Sample & Treated & Controls & Difference & S.E. & T-stat \\
\hline Food security & ATT & 0.743362832 & 0.388092489 & 0.355270343 & 0.074549345 & $4.77 * * *$ \\
Poverty status & ATT & 0.371681416 & 0.675958017 & -0.304276601 & 0.075009573 & $-4.06^{* * *}$ \\
Asset value & ATT & 80576.0885 & 76343.3504 & 4232.73805 & 4273.84219 & 0.99 \\
\hline
\end{tabular}

Sources: own result,2017. *** means significant at $1 \%$ probability level

Table 9 Impacts of irrigation use on rural livelihood outcomes

\begin{tabular}{l|cccccc}
\hline \multicolumn{1}{c|}{ Variable } & Sample & Treated & Controls & Difference & S.E. & T-stat \\
\hline Food security & ATT & 0.688311688 & 0.519774835 & 0.168536854 & 0.085451966 & $1.97 *$ \\
Asset value & ATT & 101869.156 & 69404.8037 & 32464.3521 & 16026.6178 & $2.03 * *$ \\
Poverty status & ATT & 0.402597403 & 0.57621912 & -0.173621718 & 0.086857729 & $-2.00 * *$ \\
\hline
\end{tabular}

Sources: own result, 2017. **** means significant at $5 \%$ and $10 \%$ probability level respectively

Table 10 Impacts of line planting on rural livelihood outcomes

\begin{tabular}{l|llllll}
\multicolumn{1}{c|}{ Variable } & \multicolumn{1}{c}{ Sample } & \multicolumn{1}{c}{ Treated } & \multicolumn{1}{c}{ Controls } & \multicolumn{1}{c}{ Difference } & \multicolumn{1}{c}{ S.E. } & T-stat \\
\hline Food security & ATT & 0.726315789 & 0.512524908 & 0.213790881 & 0.075009052 & $2.85^{* * *}$ \\
Poverty status & ATT & 0.315789474 & 0.645886772 & -0.330097298 & 0.072518925 & $-4.55^{* * *}$ \\
Asset value & ATT & 86666.3684 & 73228.6914 & 13437.6771 & 4070.33255 & $3.30^{* * *}$ \\
\hline
\end{tabular}

Sources: own result, 2017. $* * *$ means significant at $1 \%$ probability level

\section{Conclusions and Implications}

Increasing and sustaining agricultural productivity through investment in sustainable agricultural practices is important for the reduction of hunger and poverty in Ethiopia. In this study, I analyzed the factors determine probability of adoption of multiple agricultural technologies and their contributions to rural households livelihood outcomes by smallholder farmers in east
Oromia, Ethiopia using farm household level observations. The data were collected from 180 sample household in 2016 cropping year. Multivariate probit model is used to identify the factors that facilitate or impede the probability of the adoption of multiple agricultural technologies and propensity score matching was used for impact evaluations. 
The impact estimation results then indicate that there are significant differences in rural livelihood outcomes between treatment and comparison households, which could be attributable to the participation in climate mitigation adoption technologies. The estimation result provides a supportive evidence of statistically significant effect of adoption technologies on rural household livelihood outcomes measured by food security status, poverty status and asset accumulation. The result indicated that on average, the participant household in soil conservation has increased food security status and asset accumulation nearly by $38 \%$ and $15 \%$ respectively. Whereas as it decreases the rate of poverty nearly by 51 percent. Use of improved seeds increased food security status and decreased poverty rate nearly by $38 \%$ and $44 \%$ respectively. While the use of irrigation technology increased food security status and asset accumulation nearly by $23 \%$ and $31.8 \%$ respectively. Whereas as it decreases the rate of poverty nearly by 29 percent. Finally, adoption of line planting methods increased food security status and asset accumulation nearly by $28.7 \%$ and $15.5 \%$ respectively. Whereas as it decreases the rate of poverty nearly by 51.5 percent.

The results show that there is a strong complementarities and substitutability between agricultural technologies, indicating the interdependence of technology adoption. Studies that consider the adoption of multiple cropping technologies in isolation could lose important cross-technology correlation effects, and potentially yield biased estimates. The cross-technology correlation may have important policy implications in that a policy change that can affect one technology can have spillover effects to other technologies.

The estimated correlation coefficients results indicated that there were positive and significant relation-ships between household decision to adopt line planting and soil conservation and irrigation use and improved seed. The results also show that there were negative and significant relationships between adoption of improved seed and soil conservation; and adoption of irrigation and soil conservations. And also there were negative and significant relationships between adoption of improved seed and line planting; and adoption of irrigation and line planting. The estimation results indicated that the variables affecting farmers' decisions to adopt a technology differ between technologies. Most importantly, the results show that the probability of adoption of agricultural technologies are influenced by several factors: family size, economic active members, education level, age the household head, social status, soil fertility status, extension office distance, land holding, distance to markets and distance to weather road.

The significant role of social capital on adoption suggests the need for establishing and strengthening local institutions and service providers to accelerate and sustain technology adoption. In a country where there is information asymmetry and where both input and output markets are missing or incomplete, local institutions can play a critical role in providing farmers with timely information, inputs and technical assistance.

\section{Acknowledgments}

The authors sincerely acknowledge the district's development agents and rural development office for helping us in obtaining relevant data and information. The authors would also like to express their gratitude to the farming community as well as researchers and staff members of Haramaya University who assisting this study in one way or another.

\section{References}

Apata G, Samuel D, Adeola AO. 2009. Analysis of climate change perception and adaptation among arable food crop farmers in South Western Nigeria. Contributed paper prepared for presentation at the International Association of Agricultural Economists' 2009 conference, Beijing, China, August 16 (Vol. 22).

Arimi K. 2014. Determinants of climate change adaptation strategies used by rice farmers in South western, Nigeria. Journal of Agriculture and Rural Development in the Tropics and Subtropics, 115 (2): 91-99.

Conway D, Schipper ELF. 2011. Adaptation to climate change in Africa: Challenges and opportunities identified from Ethiopia. Global Environmental Change, 21 (1): 227237.https://doi.org/10.1016/j.gloenvcha.2010.07.013

Cooper P, Dimes J, Rao KPC, Shapiro B, Shiferaw B, Twomlow S. 2008. Coping better with current climatic variability in the rain-fed farming systems of sub-Saharan Africa: An essential first step in adapting to future climate change? Agriculture, Ecosystems\&Environment, 126 (1): 2435.https://doi.org/10.1016/j.agee.2008.01.007

Challa Merga. 2013. Determining Factors and Impacts of Modern Agricultural Technology Adoption in West Wollega, Munich, GRIN Publishing GmbH, http://www.grin.com/en/e-book/280336/determiningfactors-and-impacts-of-modern-agricultural-technologyadoption

CSA. 2016. Agricultural sample survey 2015/16. Report on land Utilization by Private Peasant Holdings. Statistical Bulletin, number 446. Central Statistical Agency, Addis Ababa, Ethiopia.

Caister K, Green M, Worth S. 2012. Learning how to be participatory: An emergent research agenda. Action Research, 10(1): 22-39. https://doi.org/10.1177/ 1476750311414737

Carletto C, Zezza A, Banarjee R. 2012. Towards better measurements of household Food Security: Harmonizing Indicators and the Role of Household Surveys. Global Food Security.

Coates J. 2013. Build it back better: deconstructing food security for improved measurement and action. Global Food Security, 2(3): 188-194. https://doi.org/10.1016/ j.gfs.2013.05.002

De Haen H, Klasen S, Qaim M. 2011. What do we really know? Metrics for food insecurity and undernutrition. Food Policy, 36(6): 760-769. https://doi.org/10.1016/j.foodpol.2011.08.003

De Weerdt J, Beegle K, Friedman J, Gibson J. 2014. The challenge of measuring hunger. World Bank Development Working Group Policy Working Paper 6736.

Ericksen PJ, Thornton PK, Notenbaert A, Cramer L, Jones P, Herrero M. 2011. Mapping hotspots of climate change and food insecurity in the global tropics. CCAFS Report No. 5, CGIAR Research Pro-gram on Climate Change. 
FAO. 2014. Socio-economic context and role of agriculture. Information reported derived from and prepared by the Food and Agriculture Policy Decision Analysis (FAPDA) team. Country fact sheet on food and agriculture policy trends, October 2014, Jain R. Arora A \& Raju S. 2009. A Novel Adoption Index of Selected Agricultural Technologies: Linkages with Infrastructure and Productivity: Agricultural Economics Research Review22; pp 109-120

Jones AD, Ngure FM, Pelto G, Young SL. 2013. What Are We Assessing When Measure Food Security? Compendium and Review of Current Metrics. Adv. Nutr. Int. Rev. J. 4, 481505.https://doi.org/10.3945/an.113.004119

Kassie M, Shiferaw B, Muricho G. 2011. Agricultural technology, crop income, and poverty alleviation in Uganda. World Development 39: 1,784-1,795

Lin CT J, Jensen K, Yen T. 2005. Awareness of food borne pathogens among US consumers. Food Quality and Preference, 16 (5), 401-412. https://doi.org/10.1016/ j.foodqual.2004.07.001

Lobel DB, Schlenker W, Costa-Roberts J. 2011. Climate trends and global crop production since 1980.Science, 333 (6042), 616-620. https://doi.org/10.1126/science.1204531

Müller C, Cramer W, Hare WL, Lotze-Campen H. 2011. Climate change risks for African agriculture. Proceedings of the National Academy of Sciences, 108 (11): 4313-4315. https://doi.org/10.1073/pnas.1015078108

Moyo S, Norton W, Alwang J, Rhinehart I, Demo C. 2007. Peanut research and Poverty Reduction: Impacts of variety improvement to control peanut viruses in Uganda. American Journal Agricultural Economics, 89(2): 448-460 https://doi.org/10.1111/j.1467-8276.2007.00991.x

MoFED. 2013. Growth and Transformation plan (GTP) Vol.1,2010/11-2014/15

Moltedo A, Troubat N, Lokshin M, Sajaia Z. (Eds.). 2014. Analyzing food security using household survey data: streamlined analysis with ADePT software. World Bank Publications. https://doi.org/10.1596/978-1-4648-0133-4

NPC. 2016. National Planning Commission. Federal Democratic Republic of Ethiopia Growth and Transformation Plan II. Volume I: NPC May, 2016, Addis Ababa.

Newton AC, Johnson SN, Gregory J. 2011. Implications of climate change for diseases, crop yields and food security. Euphytica, 179 (1): 3-18. https://doi.org/10.1007/s10681011-0359-4

Petheram L, Zander K, Campbell M, High C, Stacey N. 2010. 'Strange changes': Indigenous perspectives of climate change and adaptation in NE Arnhem Land (Australia). Global Environmental Change, 20 (4): 681-692. https://doi.org/10.1016/j.gloenvcha.2010.05.002

Pryo SC, Scavia D, Downer C, Gaden M, Iver-son L, Nordstorm R, Patz J, Robertson GP. 2014. Midwest. In: Melillo, J. M., Terese (T.C.) Richmond \& Yohe, G. W. (eds.), Climate Change Impacts in the United States: The Third National Climate Assessment. ch. 18, pp. 418-440, U.S. Global Change Research Program, Washington, D.C.
Rosenzweig C, Elliott J, Deryng, D, Ruane AC, Müller C, Arneth A, Boote J, Folberth C, Glotter M, Khabarov N, Neumann K, Piontek F, Pugh T M, Schmid E, Stehfest E, Yang H, Jone, JW. 2014. Assessing agricultural risks of climate change in the 21 st century in a global grid-ded crop model intercomparison. Proceedings of the National Academy of Sciences, 111 (9): 3268-3273. https://doi.org/10.1073/pnas.1222463110

Porter C. 2012. Shocks, Consumption and Income Diversification in Rural Ethiopia. J. Dev. Stud. 48, 12091222. https://doi.org/10.1080/00220388.2011.646990

Rosenbaum PR, Rubin DB. 1983. The Central Role of the Propensity Score in Observational Studies for Causal Effects. Biometrika, 70(1): 41-55. https://doi.org/ 10.1093/biomet/70.1.41

Simtowe F. 2011. Determinants of Agricultural Technology adoption: the Case of Improved Pigeon pea Varieties in Tanzania

Schlenker W, Lobell DB. 2010. Robust negative impacts of climate change on African agriculture. Environmental Research Letters, 5 (1): 1-8. https://doi.org/10.1088/17489326/5/1/014010

Shiferaw B, Prasanna BM, Hellin J, Bänziger M. 2011. Crops that feed the world 6. Past successes and future challenges to the role played by maize in global food security. Food Security, 3 (3): 307-327. https://doi.org/10.1007/s12571011-0140-5

Skoufias E, Rabassa M, Olivieri S. 2011. The poverty impacts of climate change: a review of the evidence. World Bank Policy Research Working Pa-per No. 5622, The World Bank, Washington, DC.https://doi.org/10.1596/1813-94505615

Sowunmi FA. 2010. Effect of climatic variability on maize production in Nigeria. Research Journal of Environmental and Earth Sciences, 2 (1): 19-30.

Teklewold H, Kassie M, Shiferaw B. 2013. Adoption of multiple sustainable agricultural practices in rural Ethiopia. Journal of Agricultural Economics, 64(3): 597623.https://doi.org/10.1111/1477-9552.12011

UNDP. 2015. Ethiopia: economic and social indicators. Ethiopia policy advisory unit, No. 2.

World Bank Group. 2016. Global Monitoring Report 2015/2016: Development Goals in an Era of Demographic Change. Overview booklet. World Bank, Washington, DC.

World Bank Group. 2013. Ethiopia's Productive Safety Net Program (PSNP) Integrating Disaster and Climate Risk Management. Case Study. The World Bank. 